\title{
Representasi Perempuan Dalam Pemberitaan KDRT di Media Massa Pada Masyarakat di Wilayah Jakarta (Studi Pemberitaan Kekerasan Dalam Rumah Tangga di Merdeka.com dan Kompas.com)
}

Woman's Representation by Mass Media Incase of Domestic Violance in Jakarta

(Content Analysis of Domesic Violence by Merdeka.com and Kompas.com)

\author{
Fauziah dan Armis Tamampil \\ Dosen Ilmu Komunikasi Universitas 17 Agustus 1945 Jakarta \\ Jl. Sunter Permai Raya, Jakarta 14350
}

fauziah@uta45jakarta.ac.id

\begin{abstract}
This study aims to identify the representation of women in the news texts at Merdeka and Kompas online. This study is a discourse analysis using a critical paradigm, through a qualitative approach. The sample selection is done using a technique purposive rubric. The analysis used is critical discourse analysis combined with analytical methods Sara Mills. After the analysis we concluded that the text of the news about the domestic violence, the position of the subject tend to be dominated by men, while women are always positioned as an object. The author positioned himself as a man, so the text message displayed also directs the reader to interpret the text of the news in the article from the point of view of men. The text of the news to be biased in representing women. Women are portrayed as a trigger to violence and eventually became a victim of domestic violence committed by men. Context is also visible in public life in Indonesia, where women as victims of domestic violence are always identical.
\end{abstract}

Key Words: Representation, Women Violence, Online Media 


\begin{abstract}
Abstraksi:
Tujuan Penelitian ini adalah untuk mendeskripsikan dan menganalisa bagaimana teks pemberitaan kekerasan dalam rumah tangga (KDRT) terhadap perempuan dihadirkan di media massa online khususnya Merdeka dan Kompas online edisi April sampai Agustus 2013. Karena itu suatu analisis isi yang lebih mendalam dan detail untuk memahami produk isi media dan mampu menghubungkanya dengan konteks sosial atau realitas yang terjadi sewaktu pesan dibuat. Karena semua pesan (teks, simbol, gambar dan sebagainya adalah produk sosial dan budaya masyarakat). Sesuai dengan rumusan permasalahan pada penelitian, metode penelitian ini menggunakan pendekatan kualitatif dengan melakukan analisis isi kualitatif terlebih dahulu terhadap pemberitaan di Merdeka dan Kompas online, kemudian baru dilakukan analisis wacana kritis dari Sara Mills untuk mengetahui perspektif pembaca dan penulis yang ditampilkan dalam teks pemberitaan tersebut. Berdasarkan analisis terhadap berita KDRT pada kedua mediaterse but dapat disimpulkan, antara lain. Penulis memposisikan dirinya sebagai laki-laki, sehingga teks berita yang ditampilkan pun mengarahkan pembaca untuk menafsirkan teks berita dalam artikel tersebut dari sudut pandang laki-laki. Dalam berita yang terkait dengan KDRT merepresentasikan perempuan (istri) sebagai objek. Teks berita tersebut menjadi bias dalam merepresentasikan perempuan karena dalam teks berita tersebut suara perempuan (istri) tidak benar-benar ditunjukkan. Perempuan hanya digambarkan sebagai pemicu tindakan kekerasan dan akhirnya menjadi korban KDRT yang dilakukan oleh laki-laki (suami)
\end{abstract}

Kata Kunci: Representasi Perempuan, KDRT, Media Online 


\section{PENDAHULUAN}

Kekerasan yang berbasis gender, pada dasarnya merupakan kekerasan dimana yang menjadi korbannya adalah perempuan baik di lingkungan rumah tangga maupun di luar lingkungan rumah tangga. Dari berbagai jenis kekerasan yang berbasis gender, seperti perkosaan, pelacuran, pornografi, pelecehan seksual, dsb. Ternyata yang paling menonjol saat ini adalah kekerasan dalam rumah tangga (domestic violence), yang dapat digolongkan kepada tindakan kejahatan seperti pemukulan dan serangan fisik dalam rumah tangga (Rika.S 2006: 16).

- Masalah Kekerasan Dalam Rumah Tangga (KDRT) bukan hanya masalah intern keluarga, tapi sudah menjadi persoalan publik. Salah satu penyebab terjadinya kekerasan dan lemahnya perlindungan hukum bagi wanita korban di Indonesia, kemungkinan dikarenakan

eksistensi dari adanya sistem budaya patriarkal di masyarakat, di mana sistem pranata sosial ini mendasarkan pada relasi yang timpang menurut kategori kuat-lemah, pihak yang kuat menguasai dan menindas pihak yang lemah ataupun sistem budaya sosial yang memarjinalkan posisi wanita secara tetap di masyarakat, di mana seolah-olah melegitimasi berbagai macam ketidakadilan, perampasan dan penindasan yang dilakukan pelaku atas hak asasi wanita korban (Murniati, 2004: 227-229). 
Selain itu, media massa juga mempunyai potensi sebagai pemicu munculnya bentuk bentuk realitas ketimpangan hubungan sosial (social relationships (baca: kekerasan)) dalam kehidupan bermasyarakat. Sosok wanita oleh media massa, baik melalui iklan atau beritanya, selalu dideskripsikan secara negatif dan sangat tipikal yaitu tempatnya wanita ada di rumah, berperan tunggal sebagai ibu rumah tangga dan pengasuh, tergantung pada pria, menjalani profesi secara terbatas, tidak mampu membuat keputusan penting, selalu melihat dirinya sendiri, sebagai objek seksual/ simbol seks (sexploitation, pornographizing), objek peneguhan pola kerja patriarki, objek fetish, objek pelecehan dan kekerasan, selalu disalahkan (blaming the victim) dan bersikap pasif, serta sebagai alat pembujuk/ negosiasi. Eksistensi wanita tidak terwakili pula secara proporsional di media massa, entah dalam industri media hiburan atau dalam industri media berita (Wolf dalam Sunarto, 2009: 4).

Media seolah mengajak khalayak untuk mengetahui bagaimana proses terjadinya kekerasan, khalayak sepertinya digiring oleh media untuk ikut menyalahkan korban (blaming the victim), sebagaimana ditunjukkan oleh Data Monitoring LRCKJHAM (2009: 17), yaitu sebagai berikut: Pelaku mengaku membunuh korban/ PSK yang berusia 30 tahun, dikarenakan korban tidak mampu melayani nafsu pelaku (19 tahun) sampai tuntas, padahal pelaku sudah menyerahkan uangnya sebesar 100 ribu. Korban melayani satu kali, lalu merasa tidak cukup, pelaku 
meminta lagi, namun korban menolak dan dibunuh pelaku dengan batu besar. Pelaku menghantamkan batu ke kepala korban sebanyak delapan kali, lalu pelaku meninggalkan korban begitu saja di tambak, karena ada orang yang datang. Pelaku kini ditahan di Polres Kendal (Surat Kabar Harian 'Suara Merdeka', 18 Agustus 2008).

Dalam perkembangannya, kasus KDRT tidak lagi merupakan persoalan pribadi keluarga itu sendiri, tapi menjadi urusan publik. Sehingga KDRT banyak diketahui masyarakat luas, ditayangkan di media massa, menjadi konsumsi publik, terkuak pelaku maupun korbannya dan bisa menarik perhatian banyak orang. Dalam pemberitaan KDRT di media massa terlihat, korban terbanyak adalah perempuan, karena perempuan dianggap memiliki banyak kelemahan, terutama kelemahan fisik.

Berdasarkan latar belakang masalahnya, maka ditentukan Perumusan Masalah penelitian ini adalah: Bagaimana representasi perempuan terhadap teka pemberitaan KDRT pada masyarakat di wilayah DKI Jakarta pada Merdeka dan Kompas online edisi April sampai Agustus 2013? Bagaimana Analisis pembaca terhadap pemberitaan KDRT di media massa pada Merdeka dan Kompas online? Bagaimana Analisis penulis terhadap pemberitaan KDRT di media massa pada Merdeka dan Kompas online? 


\section{KERANGKA TEORI}

\section{A. Representasi Perempuan dalam Media}

Sebuah wacana dapat menjadi sarana sekaligus media bagi satu kelompok yang memiliki dominasi dibandingkan dengan kelompok lain. Dalam kondisi ini, representasi menjadi aspek yang penting. Istilah representasi merujuk pada bagaimana kelompok, seseorang, gagasan atau pendapat tertentu ditampilkan dalam sebuah wacana.

Wacana-wacana tersebut berada di bawah permukaan representasi untuk menghasilkan makna, misalnya dikaitkan dengan ilmu pengetahuan yang menganggap bahwa secara alami perempuan tidak mampu untuk memperbaiki mobil, atau dikaitkan dengan wacana kesehatan yang mengatakan bahwa perempuan dianggap memiliki lebih banyak masalah kesehatan dibanding laki-laki.

Wacana mencakup dukungan terhadap perbedaan kekuasaan dan gagasan mengenai perempuan yang lebih emosional dibanding laki-laki yang mengedepankan logika, sehingga emosi tersebut dianggap sebagai tanda kelemahan (Graeme 2007, 292-293).

\section{B. Analisis Feminis (Gender)}

Banyaknya pendekatan dan teori tentang permasalahan perempuan menyebabkan munculnya perbedaan dalam analisis dan pemahaman tentang penindasan dan eksploitasi terhadap 
kaum perempuan. Permasalahan perempuan pun terentang dalam spektrum yang luas; mulai dari benak setiap individu, tafsir agama, sampai institusi negara. Sehingga upaya penegakan keadilan gender dapat berarti juga sebagai upaya menggugat privilege yang dinikmati sebagian kelompok masyarakat diantaranya adalah perempuan.

Menurut Ratna (2007, 184), dalam realita, hanya seks, yakni laki-laki- perempuan yang ditentukan secara kodrati. Sementara itu, jender (maskulin-feminim) lebih ditentukan secara budaya sebagai pengaturan kembali infrasruktur material dan superstruktur ideologis. Sehingga para feminis sangat menolak anggapan bahwa perempuan merupakan konstruksi negatif, makhluk takluk, makhluk inferior, dan makhluk kelas dua. Baik laki-laki maupun perempuan, dapat menjadi pusat maupun nonpusat. Hal ini bergantung pada posisi dan kondisinya dalam masyarakat

Berdasarkan Webster's New Dictionary dimaknai sebagai perbedaan yang tampak antara laki-laki dan perempuan dilihat dari segi nilai dan tingkah laku (Hamdani 2008, 146). Gender merupakan sifat yang melekat pada laki- laki dan perempuan yang dikonstruksi secara sosial dan budaya. Misalnya, di masyarakat tumbuh anggapan bahwa laki-laki itu kuat, berlandaskan pada rasio, jantan, dan gagah. Sedangkan perempuan misalnya dianggap memiliki sifat lemah lembut, emosional, dan keibuan. Gender ini bisa berubah dan bertukar, 
maksudnya ada laki-laki yang juga memiliki sifat lemah lembut, dan sebaliknya ada perempuan yang kuat dan perkasa (Fakih 1999, 7-9).

Dari pemberitaan di media massa terkait dengan kekerasan terhadap perempuan dalam rumah tangga, seringkali menunjukkan perempuan sebagai objek dari pemberitaan tersebut. Perempuan yang telah dikonstruksikan sebagai objek yang lemah oleh masyarakat, di dalam media semakin dikukuhkan sebagai korban yang tertindas oleh kekuasaan lakilaki.

Beberapa istilah yang harus dipahami dalam melakukan analisis gender, diantaranya

1. Gender adalah konsep yang mengacu pada peran-peran dan tanggungjawab laki-laki dan perempuan yang terjadi akibat dari dan dapat berubah oleh keadaan sosial dan budaya masyarakat.

2. Kesetaraan Gender adalah kesamaan kondisi bagi laki-laki dan perempuan untuk memperoleh kesempatan dan hakhaknya sebagai manusia, agar mampu berperan dan berpartisipasi dalam kegiatan politik, ekonomi, social budaya, pertahanan dan keamanan nasional, dan kesamaan dalam menikmati hasil pembangunan.

3. Keadilan Gender adalah suatu proses untuk menjadi adil terhadap laki-laki dan perempuan.. 
4. Responsif Gender adalah kebijakan/ program/ kegiatan yang sudah memperhitungkan laki- laki dan perempuan.

5. Netral Gender adalah kebijakan, program, kegiatan atau kondisi yang tidak memihak pada salah satu jenis kelamin (Pusat Studi wanita, UNY, 2003).

\section{Analisis isi (content analysis) Kualitatif}

Analisis isi kualitatif memfokuskan risetnya pada isi komunikasi yang tersurat (tampak atau manifest). Karena itu tidak dapat digunakan untuk mengetahui isi komunikasi yang tersirat (latent). Misalnya mengapa Harian Kompas memberitakan berita KDRT dengan cara berbeda dengan harian Merdeka. Karena itu diperlukan suatu analisis isi yang lebih mendalam dan detail untuk memahami produk isi media dan mampu menghubungkanya dengan konteks sosial atau realitas yang terjadi sewaktu pesan dibuat. Karena semua pesan (teks, simbol, gambar dan sebagainya adalah produk sosial dan budaya masyarakat).

\section{Analisis Wacana Kritis Sara Mills}

Pendekatan perspektif feminis Sara Mills lebih menekankan bagaimana perempuan dicitrakan dalam teks berita. Dengan konsep bagaimana posisi aktor-aktor dalam teks berita, akan didapatkan siapa yang dominan menceritakan kejadian (sebagai subjek) serta posisi yang ditarik ke dalam 
berita. Pendekatan perspektif feminis memberikan gambaran pada kita bagaimana citra perempuan dalam berita. Atau dalam konteks penelitian ini, yang hanya mengangkat berita-berita kriminal pelecehan seksual dan pemerkosaan terhadap perempuan. Apakah perempuan cenderung dirugikan dengan menempatkan perempuan dalam posisi menafsirkan kejadian. Bagaimana posisi pembaca di dalam teks berita tersebut.

Sara Mills memusatkan perhatiannya pada wacana tentang perempuan. Titik perhatian dari analisis wacana adalah menunjukkan bagaimana wanita digambarkan dan dimarjinalkan dalam teks berita dan bagaimana bentuk dan pola pemarjinalan itu dilakukan, sehinna ketika ditampilkan dalam teks, wanita tergambar secara buruk. kemudian bagaimana perempuan ditampilkan dalam teks, dalam novel, gambar, foto ataupun berita. Sering juga disebut pendekatan wacana ini disebut sebagai perspektif Sara Mills. Titik perhatian dari perspektif wacana feminis adalah menunjukkan bagaimana teks bias dalam menampilkan perempuan. Perempuan cenderung ditampilkan dalam teks sebagai pihak yang salah, marjinal dibandingkan dengan pihak laki-laki (Eriyanto, 2001:198-199).

Konsep Sara Mills dalam memandang wacana berbeda dengan konsep wacana yang lain yang kebanyakan menggunakan pendekatan critical linguistic. Sara Mills lebih melihat bagaimana posisi-posisi aktor ditampilkan dalam teks. Dalam arti siapa yang menjadi subjek penceritaan dan siapa 
yang menjadi objek penceritaan. Dengan demikian akan didapatkan bagaimana struktur teks dan bagaimana makna diperlakukan dalam teks secara keseluruhan.

Juga bagaimana pembaca dan penulis diperlakukan dalam teks. Bagaimana pembaca mengidentifikasi dan menempatkan dirinya dalam penceritaan teks. Posisi semacam ini akan menempatkan pembaca pada salah satu posisi dan mempengaruhi bagaimana teks itu ditampilkan. Pada akhirnya cara penceritaan dan posisi-posisi yang ditempatkan dan ditampilkan dalam teks ini membuat satu pihak menjadi legitimate dan pihak lain menjadi illegitimate.

Ada dua konsep inti dalam analisis wacana Sara Mills, yakni posisi subjek-objek dan posisi penulis-pembaca. Dalam konsep pertama, digunakan untuk melihat posisi subjek yang memberikan penafsiran atas sebuah peristiwa dan terhadap orang lain yang menjadi objek yang ditafsirkan. Di sini harus jelas siapa yang mengatakan apa terhadap siapa, sehingga jelas ia berada dalam posisi subjek ataukah objek, sebagai pencerita atau yang diceritakan, siapa yang memiliki "kuasa" untuk menafsirkan kondisi dan siapa yang ditafsirkan olehnya. Dan yang penting, apa akibatnya.

Sedangkan konsep kedua yang menjadi ciri khas analisis wacana adalah tidak hanya meninjau dari sisi penulis saja, namun mencoba menggali wacana yang muncul dari sisi pembaca. Sebab Sara Mills menilai pembaca memiliki pengaruh 
ketika tulisan itu dibuat oleh penulis. Sara Mills dalam Eriyanto, menjelaskan tentang teks sebagai hasil negoisasi antara penulis dan pembaca. Pembaca dianggap bukan hanya sebagai penerima teks, tetapi ikut berperan bagaimana nantinya teks itu ditampilkan.

\section{E. Fakta}

Dalam konsepsi pluralis, diandaikan ada realitas yang bersifat external yang ada dan hadir sebelum wartawan meliputnya. Jadi, ada realitas yang bersifat objektif, yang harus diambil dan diliput oleh wartawan. Sementara bagi kaum kritis, realitas merupakan kenyataan semu yang telah terbentuk oleh proses kekuatan sosial, politik dan ekonomi. Berita adalah mirror of reality menurut pandangan pluralis, sehingga harus mencerminkan realitas yang hendak diberitakan. (Daniel, 1985:205 dalam Eriyanto, 2001:34). Sementara menurut kaum kritis, berita adalah hasil pertarungan wacana antara berbagai kekuatan dalam masyarakat yang selalu melibatkan pandangan dan ideologi wartawan atau media.

\section{III.METODOLOGI PENELITIAN}

\section{A. Batasan Penelitian}

Mengingat luasnya pemberitaan KDRT di media massa, maka dalam penelitian ini dibatasi hanya pemberitaan KDRT di Merdeka dan Kompas online. Waktu penelitian 
terhadap objek tersebut adalah pemberitaan tentang KDRT di Merdeka dan Kompas online pada bulan April sampai Agustus 2013, dengan asumsi bahwa pada bulan rentang kurun waktu tersebut 2 harian surat kabar ini banyak memberitakan KDRT, jika dibandingkan bulan-bulan sebelumnya.

\section{B. Paradigma Penelitian}

Paradigma penelitian Kritis dari Sara Mills dipergunakan pada penelitian ini. Kritis di sini artinya analisis wacana menekankan pada konstalasi kekuatan yang terjadi pada proses produksi dan reproduksi makna. Individu tidak dipandang sebagai subjek yang netral, karena sangat berhubungan dan dipengaruhi oleh kekuatan sosial yang ada di masyarakat.

Sedangkan dalam pandangan paradigma kritis bahasa tidak dipahami sebagai medium netral melainkan sebagai representasi yang berperan dalam membentuk subjek tertentu, tema-tema wacana tertentu, maupun strategi-strategi di dalamnya. Karenanya, analisis wacana digunakan untuk menguraikan segala sesuatu yang ada di dalam setiap proses bahasa. Marxis Kritis. (Stephen W. Littlejohn, 2002; Stanley J. Baran and Denis K. Davis, 2000). 


\section{Metode Penelitian}

Sesuai dengan rumusan permasalahan pada penelitian, metode penelitian ini menggunakan pendekatan kualitatif dengan melakukan analisis isi kualitatif terlebih dahulu terhadap pemberitaan di Merdeka dan Kompas online, kemudian baru dilakukan analsis wacana kritis untuk mengetahui perspekif pembaca dan penulis yang ditampilkan dalam teks pemberitaan tersebut. Mengidentifikasi dan menempatkan pembaca pada salah satu posisi sebagai aktor sosial dengan memunculkan prasangka sebelumnya terhadap objek yang diteliti.

\section{Teknik Pengumpulan Data}

Teknik pengumpulan data yang dilakukan dalam penelitian ini diawali dengan mengumpulkan berita KDRT yang dipublikasikan di Merdeka dan Kompas on line. Peneliti mengambil sampel berita KDRT yang dipublikasikan selama bulan April - Agustus 2013. Alasan pemilihan rentang waktu tersebut atas dasar anggapan bahwa topik yang muncul selama bulan tersebut telah merepresentasikan tema yang ingin diangkat yaitu tentang kekerasan terhadap perempuan dalam rumah tangga. Selain itu disebabkan adanya keterbatasan waktu penelitian, sehingga dianggap perlu untuk membatasi rentang waktu Merdeka dan Kompas online yang memberitakan kasus KDRT yang dijadikan sumber analisis wacana ini. 
Setelah mengumpulkan berita tentang KDRT yang terbit selama bulan April - Agustus 2013, peneliti memperoleh tema yang beragam dari mulai tema perselingkuhan, KDRT, tindak kriminal, pelecehan seksual, penipuan, dan lain lain. Peneliti menyeleksi kembali semua rubrik tersebut, dan secara purposive hanya memilih rubrik dengan tema yang benar-benar merepresentasikan kekerasan terhadap perempuan dalam rumah tangga.

Selanjutnya, peneliti melakukan studi pustaka, yakni berupa kegiatan pengumpulan bahan-bahan acuan yang relevan dengan penelitian ini melalui teks-teks tertulis seperti buku, $e$ book, artikelartikel dalam majalah, surat kabar, buletin, jurnal, makalah, dan lain-lain. Peneliti kemudian melakukan analisa terhadap isi berita KDRT di Merdeka dan Kompas online. Hal ini dilakukan untuk mengetahui karakteristik ideologi tersembunyi dalam bahasa, yang dikemas menjadi sebuah cerita.

\section{IV.PEMBAHASAN}

\section{A. Analisa posisi subjek}

Pada berita di Kompas online yang terbit pada tanggal 16 Juli 2012 berjudul "Lontong Anak di makan Ibu KDRT pun terjadi “, yang berlaku sebagai subjek (pencerita) dalam rubrik ini adalah MK (lakilaki/suami). Hal ini terlihat pada paragraf ke dua: persoalan timbul karena lontong yang 
disediakan untuk sarapan anaknya kemudian dimakan oleh korban. Suaminya langsung berang, begitu melihat makanan anaknya sudah ludes. Dengan diposisikannya MK sebagai subjek, dia bebas menceritakan dirinya dan tindakannya dari sudut pandangnya sendiri. Hal ini membuat MK seolah-olah menjadi narator cerita. Sedangkan representasi pihak lain (dalam hal ini istrinya) ditampilkan menurut persepsi dan pendapatnya.

Pada Kompas 12, April 2013 dengan judul berita “Tak Terima Ditegur, Suami Tega Bakar Istri suaminya tersebut ". Hal ini terlihat dalam paragraf kesatu dan kedua: lantaran menegur suaminya LS (27) yang jarang pulang, RA (22) menjadi korban kekerasan rumah.Tak dinyana, LS tersinggung karena ditegur sang istri. Dia lalu menyiramkan bensin ke tubuh RA dan kemudian membakar istrinya itu. Motifnya di duga karena suami jarang pulang RA menegur suaminya.

Merdeka online pada Selasa, 9 Juli 2013, dengan judul "Sudah dipaksa jadi PSK, wajah Yan juga disilet suami". Posisi subjek terlihat pada paragraf kelima dan ketujuh: Saat itu, korban yang berada di lokasi liar Pela-Pela Tanjung Priok, tiba-tiba didatangi tersangka dan langsung mengiris wajah istrinya menggunakan pisau silet. Yan mengaku dipaksa suaminya menjadi pekerja seks komersil 
(PSK) sejak dua tahun lalu. Jika tidak mau menuruti kemauan suaminya, Ibu beranak satu ini sering dipukuli.

Sementara pada Merdeka tanggal 2, Agustus 2013, dengan judul berita "Cornelia Agatha, Ajukan Bukti KDRT, Langsung Resmi Janda". Terlihat pada paragraf lima, enam dan tujuh : biduk rumah tangga Lia dan Sony sudah retak. Sony bisa dibilang sudah tak bertanggung jawab lagi sebagai suami. "Hal itu disebabkan oleh suami jarang pulang ke rumah dan jarang tidur di rumah. Suami juga sering mencaci maki penggugat,". Ditambahkan, penyebab utama perceraian adalah banyaknya pertengkaran yang sering dipicu masalah sepele. Disinyalir, Lia juga mengalami KDRT (Kekerasan Dalam Rumah Tangga).

\section{B. Analisis Posisi Objek}

Pemberitaan KDRT di Kompas online yang berjudul “Lontong Anak di makan Ibu KDRT pun terjadi", yang terbit pada hari Senin, 16 Juli 2012, menempatkan DYI (perempuan/istri) sebagai korban yang dipaparkan oleh si pelaku digabung dengan gagasan penulis, hal ini terlihat pada paragraf ketiga: klimaksnya "Dia memukul dan menjambak rambut saya sampai saya jadi begini," kata DYI di hadapan penyidik. Akibat penganiayaan itu, DYI mengalami luka memar di bagian kepala dan wajah. DYI yang tak terima dianiaya suami karena alasan sepele itu pun memutuskan 
melapor ke pihak kepolisian. Pihak Pemberdayaan Perempuan dan Anak (PPA) yang dikonfirmasi perihal kasus ini enggan mengungkapkan secara terbuka.

Keseluruhan teks ini serta ikut menceritakan kronologis peristiwa yang menimpa dirinya tersebut. Namun hal ini tidak mampu menunjukkan kekuatan DYI dalam menghadapi suaminya yang kasar. Hal tersebut ditunjukkan dari teks yang ada dalam paragraf kedua tersebut, terlihat bahwa DYI juga diposisikan sebagai objek sekaligus korban dari tindak kekerasan yang dilakukan oleh MK. Peristiwa tersebut dijelaskan dari sudut pandang laki-laki, dimana terdapat argumen bahwa alasan DY menempeleng istrinya karena dia sudah mengingatkan untuk tidak makan lontong anaknya tapi tidak digubris oleh istrinya. Posisi DYI sebagai objek, membuat dia tidak memperoleh kesempatan untuk bercerita dari sudut pandangnya.

Berita yang berjudul "Tak Terima Ditegur, Suami Tega Bakar Istri “, pada Kompas online 12, April 2013 memosisikan LS sebagai objek yang menjadi korban KDRT oleh suaminya, RA. Hal ini dapat dilihat dari paragraf ke dua: “Tak dinyana, LS tersinggung karena ditegur sang istri. Dia lalu menyiramkan bensin ke tubuh RA dan kemudian membakar istrinya itu. Sebagai korban KDRT, LS ditempatkan pada posisi sebagai objek. Kronologis kejadian KDRT tersebut ditulis dari sudut pandang si pelaku (RA ). 
Disini Rani dilihat sebagai perempuan yang pasif dan menerima perlakuan apa saja dari suaminya tersebut.

Merdeka online pada Selasa, 9 Juli 2013 dengan judul berita "Sudah dipaksa jadi PSK, wajah Yan juga disilet suami”, Yan sebagai korban diposisikan sebagai objek oleh suaminya Wibi. Terlihat pada paragraf kesatu dan kedua : Sungguh malang nasib yang menimpa Yan. Wanita 30 tahun ini mempunyai suami yang super bejat. Sang suami, Wibi Ahmad Jajuli tega menjualnya di tempat prostitusi 'Pelapela', Tanjung Priok, Jakarta Utara.Hanya itu, Wibi juga tega menyilet wajah istrinya itu dengan menggunakan silet, alhasil 22 luka jahitan bersarang di muka sang istri. Di kasus ini Yan pasrah menerima perlakuan dari suaminya yang bejat. Setelah dijual dan dipaksa bekerja di lokalisasi untuk memenuhi kebutuhan ekonominya, Yan diambil paksa dilokalisasi ketika Yan bekerja, disiksa suaminya Wibi dengan menyilet wajahnya didepan orang banyak.

Pada judul berita KDRT di Merdeka online selanjutnya pada Jum'at 2, Agustus 2013, yang berjudul “Cornelia Agatha, Ajukan Bukti KDRT, Langsung Resmi Janda“ juga terlihat penempatan objek dari pihak perempuan, dalam hal ini yang bertindak sebagai objek adalah Lia, yang disinyalir mengalami KDRT dari suaminya Sony, seperti pada tulisan di paragraf Pertama : Ada bukti foto bahu dan pipi yang memar. Lia ogah menjelaskan, biar 
polisi saja yang mengurus. Dan pada tulisan di paragraf keenam dan ketujuh : Hal itu disebabkan oleh tergugat jarang pulang ke rumah dan jarang tidur di rumah. Tergugat juga sering mencaci maki penggugat. Disinyalir, Lia juga mengalami KDRT (Kekerasan Dalam Rumah Tangga) sebagai juru warta kebenaran. Padahal dalam kenyataannya belum tentu yang disampaikan sesuai dengan faktanya. Pada paragraf tersebut seolah ditampilkan. Hal tersebut juga menunjukkan bahwa posisi wanita dianggap masih cukup lemah dalam menghadapi dominasi laki-laki.

\section{Analisis Posisi Penulis}

Dalam teks yang berjudul "Lontong Anak Dimakan Ibu, KDRT Pun Terjadi”, yang terbit pada hari Senin, 12 Juli 2012 di Harian Kompas, digambarkan bahwa penulis memposisikan diri sebagai laki-laki. Hal ini ditampilkan salah satunya dalam paragraf terakhir. "Kami belum mendapat laporan," kata Kanit PPA Polres Metro Jaksel Iptu Nunu saat dihubungi Kompas.com. Belum diketahui apakah kasus ini akan diproses secara hukum ataukah akan diselesaikan secara kekeluargaan. Artinya penulis mengambangkan kasus ini seolah-olah kasus ini hanya kasus biasa, yang dapat diselesaikan secara mudah dan tanpa harus melalui proses hukum. 
Pada berita di Kompas pada Jum'at 12 April 2013 dengan Judul berita “ Tak Terima Ditegur, Suami Tega Bakar Istri" Kalimat tersebut menunjukkan bahwa penulis memposisikan diri sebagai laki-laki karena cenderung permisif terhadap perilaku kekerasan. Penulis seolah-olah membenarkan perilaku melakukan Kekerasan asalkan seseorang itu mampu secara fisik. Seharusnya penulis dapat bersikap netral karena kekerasan fisik ditinjau dari sudut manapun seharusnya tidak dapat dibenarkan.

Kemudian Merdeka online pada Selasa, 9 Juli 2013 yang berjudul "Sudah dipaksa jadi PSK, wajah Yan juga disilet suami", teks tersebut memosisikan penulis sebagai laki-laki yang bercerita. Terlihat pada paragraf keempat dan keenam : Saat itu, korban yang berada di lokasi liar Pela-Pela Tanjung Priok, tiba-tiba didatangi tersangka dan langsung mengiris wajah istrinya menggunakan pisau silet. Spontan area tempat prostitusi itu menjadi heboh. Yan "mengaku" dipaksa suaminya menjadi pekerja seks komersil (PSK) sejak dua tahun lalu. Jika tidak mau menuruti kemauan suaminya, Ibu beranak satu ini sering dipukuli.

Dalam teks ini penulis menggambarkan seolah-oleh dibenarkan perilaku melakukan kekerasan seenaknya dan dimanapun. Dengan penggunaan kata "mengaku" seolaholah penulis meyakinkan pembaca dari sudut pandangnya bahwa ada keraguan dari pernyataan Yan yang dipaksa 
suaminya menjadi PSK. Analisa penulis kalau dipaksa sebagai PSK bagaimana korban bisa bertahan bekerja selama dua tahun, kenapa korban selama itu tidak meminta pertolongan atau lari ketika dipaksa menjadi PSK dan disiksa suaminya.

Sementara dalam teks berita di Merdeka tanggal 2, Agustus 2013 yang berjudul "Cornelia Agatha, Ajukan Bukti KDRT, Langsung Resmi Janda”, penulis turut memposisikan dirinya sebagai laki-laki. Hal ini terlihat dalam paragraf terakhir: Ia memang tak mau mengumbar perlakuan apa saja yang didapatnya dari sang suami selama tujuh tahun menikah."Tabu buat saya kalau mengumbar ke publik dan jadi tontonan. Itu nggak elegan, nggak bijak. Saya harus menjaga perasaan banyak orang, keluarga, anak-anak,”. Dalam hal ini Lia di gambarkan penulis sebagai sosok yang kuat walaupun sudah mengalami KDRT dari suaminya, dan penulis seolah-olah menggambarkan bahwa KDRT yang dialami Lia tabu di ketahui orang banyak karena Lia adalah artis dan dari teks Itu nggak elegan, nggak bijak, seolah-olah penulis mengajak pembaca untuk berpikir bahwa perilaku KDRT suami Lia terhadap dirinya adalah sesuatu yang tidak perlu diungkapkan karena tabu.

Dalam konteks wacana kritis, teks berita di Merdeka dan Kompas online mencoba menggambarkan situasi, latar, kondisi dan peristiwa yang cenderung 
menempatkan subjek dalam posisi laki-laki. Sehingga sebuah peristiwa diceritakan dan cara korban direpresentasikan semuanya didasarkan pada sisi pelaku yang merupakan seorang laki-laki, yang merasa memiliki kekuatan serta kemampuan untuk melakukan penganiayaan kepada istrinya. Perempuan yang diceritakan dalam berita KDRT di Merdeka dan kompas online tidak hanya dilihat sebagai suatu teks tetapi dilihat dari konteksnya yaitu perempuan merupakan pihak yang dikuasai oleh pria. Hal ini dilatarbelakangi oleh adanya ideologi patriarki yang berkembang di masyarakat. Ideologi patriarki inilah yang tercermin di penyampaian berita KDRT di merdeka dan kompas online tersebut, sehingga perempuan tidak terlalu direpresentasikan dalam pemberitaan tersebut.

Dari keseluruhan berita tentang KDRT yang dianalisis memperlihatkan bahwa penulis menandakan peristiwa dengan mengidentifikasi pelaku sebagai laki-laki, dan korbannya adalah seorang perempuan. Penulis juga mencoba menggambarkan atau menceritakan kejadian yang dominan dilihat dari sisi pelaku (laki-laki) sebagai subjek serta bagaimana perempuan cenderung dijadikan sebagai objek tindakan kekerasan, sehingga mempertegas bahwa dalam peristiwa yang diceritakan, laki-laki sebagai subjek mempunyai kekuasaan yang lebih dominan dibandingkan dengan perempuan yang terkesan hanya bisa pasrah dan tidak 
bisa berbuat apa-apa. Hal ini menunjukkan bahwa berita tentang KDRT di Merdeka dan Kompas online telah dikonsep oleh redaksi Merdeka dan Kompas online dengan bahasa dari sudut pandang laki-laki.

Dalam berita tentang KDRT di Merdeka dan Kompas online tersebut, representasi perempuan sebagai pihak yang lemah dan pasrah atas tindakan yang dilakukan suaminya, sejalan pula dengan perspektif feminis yang menunjukkan bahwa teks akan bias dalam menggambarkan perempuan, dimana dalam teks tersebut posisi laki-laki dianggap boleh melakukan apapun yang dia suka sehingga perempuan dalam hal ini istrinya harus menanggung mengalami penderitaan akibat perilaku suaminya tersebut. Hal ini didasarkan pada teori penindasan gender yang melukiskan situasi perempuan sebagai akibat dari hubungan kekuasaan langsung antara lelaki dan wanita, dimana lelaki memiliki kepentingan mendasar dan konkret untuk mengendalikan, menggunakan, menaklukan, dan menindas perempuan, sehingga memunculkan dominasi patriarki. Patriarki dianggap sebagai struktur kekuasaan primer yang dilestarikan dengan maksud yang disengaja.

Pada teks berita yang diangkat dalam berita di Merdeka dan Kompas online, perempuan cenderung ditampilkan sebagai pihak yang menjadi pemicu KDRT, karena dianggap melakukan tindakan yang tidak sopan atau 
yang tidak diinginkan suami Akhirnya sang suami merasa bahwa istrinya tersebut harus diberikan pelajaran agar sang suami tidak kehilangan kekuasaannya dalam rumah tangga dan mengendalikan istrinya. Cara yang ditempuh pun dengan melakukan tindakan kekerasan (KDRT). Dalam teks tersebut pun tidak ditunjukkan bentuk-bentuk perlawanan sang istri terhadap KDRT yang dilakukan oleh suaminya tersebut. Sehingga media pun mengangkat bahwa laki-laki merupakan pihak yang paling mendominasi, sehingga melanggengkan pemahaman bahwa sistem patriarki akan menjadi sistem yang lestari. Seiring dengan hal tersebut, perempuan akan selalu berada di posisi sebagai korban yang lemah, pasrah, serta berada di bawah dominasi dan kekuasaan laki-laki.

\section{KESIMPULAN}

Berdasarkan analisis terhadap berita KDRT pada dua harian tersebut yaitu Kompas dan Merdeka online dapat disimpulkan, antara lain: Posisi subjek (pencerita) cenderung di dominasi oleh laki-laki, sedangkan perempuan selalu diposisikan sebagai objek (yang diceritakan). Penulis memposisikan dirinya sebagai laki-laki, sehingga teks berita yang ditampilkan pun mengarahkan pembaca untuk menafsirkan teks berita dalam artikel tersebut dari sudut pandang laki-laki. Dalam berita yang terkait dengan KDRT merepresentasikan perempuan (istri) sebagai objek. Teks berita 
tersebut menjadi bias dalam merepresentasikan perempuan karena dalam teks berita tersebut suara perempuan (istri) tidak benar-benar ditunjukkan.

Perempuan hanya digambarkan sebagai pemicu tindakan kekerasan dan akhirnya menjadi korban KDRT yang dilakukan oleh laki-laki (suami).Representasi perempuan yang selalu dijadikan sebagai objek dalam teks berita terkait KDRT, dijadikan sebagai bentuk usaha untuk melanggengkan pemahaman bahwa laki-laki merupakan pihak yang menguasai perempuan. Representasi perempuan yang dianggap lemah dan pasrah serta takluk dalam kekuasaan lakilaki akhirnya menjadi lestari dalam masyarakat.

Konteks ini sejalan dengan pandangan kaum feminis yang menganggap bahwa penindasan terhadap perempuan terjadi sebagai usaha laki-laki untuk mempertahankan dominasi laki-laki terhadap perempuan.Laki-laki dianggap akan melakukan segala cara untuk melanggengkan sistem patriarki di masyarakat. Konteks ini pun terlihat dalam kehidupan bermasyarakat di Indonesia, dimana perempuan selalu identik sebagai korban KDRT. Hal ini tentunya terlihat jelas di media yang seringkali menampilkan perempuan sebagai objek atau korban dalam pemberitaan terkait dengan KDRT. 


\section{Daftar Pustaka}

Burton, Graeme, 2007, Membincangkan Televisi. Yogyakarta dan Bandung: Jala Sutra.

Beritajakarta.com, 2007, akses Jumat (11/5,2007).

Christina, Andhika Setyanti, 2012, 60 persen perempuan alami KDRT, diakses dalam situs http://regional.kompas.com/read/2012/03/12/15053582/60 .Persen.Perempuan.AlamiKDRT, di akses pada 18 April 2012.

Data Monitoring LRC-KJHAM, 2009

Eriyanto, 2009, Analisis Wacana: Pengantar Analisis Teks Wacana. Yogyakarta : LKiS Yogyakarta.

Fakih, M, 1999,Analisis Gender dan Transformasi Sosial. Yogyakarta: Pustaka Pelajar.

Fiske, John, 2001), Introduction to Communication Studies (2nd ed.). London and New York: Routledge.

Hamdani, Agus, 2008, Representasi Gender dalam Teks. Jurnal Bahasa dan Sastra Vol.8, No. 2 edisi Oktober.

Ibrahim, Idi Subandy \& Suranto, Hanif, 1998, Wanita Dan Media: Konstruksi Ideology Gender Dalam Ruang Publik Orde Baru. Bandung: Remaja Rosdakarya.

Mitra Perempuan Statistik \& Catatan 2011

Murniati, A. Nunuk P, 2004, Getar Gender (Perempuan Indonesia dalam Perspektif Sosial, Politik, Ekonomi, Hukum dan $H A M)$ (1st ed). Magelang: Yayasan Indonesia Tera (Anggota IKAPI)

Priyo. S, 2004. Media Massa dan Sensitivitas Gender. Dalam Priyo SM dan Veven Sp Wardhana (ed), Telaah Kritis Potret Perempuan Di Media Massa. Jakarta: PT. Prima media Pustaka 
Pusat Studi wanita, UNY, 2003.

Ratna, Nyoman Kutha, 2007, Teori, Metode, dan Teknik Penelitian Sastra. Yogyakarta: Pustaka Belajar.

Rika Saraswati, Rika, 2006, Perempuan dan Penyelesaian Kekerasan dalam Rumah Tangga. Bandung: PT. Citra Aditya Bakti

Ritzer, George \& J. Goodman Douglas, 2008, Teori Sosiologi Modern. Edisi ke-6. Jakarta: Kencana.

Shoemaker, Pamela J. \& Stephen D. Reese, 1996, Mediating The Message: Theories of Influences on Mass Media Content. London: Longman.

Sobur, Alex, 2009, Analisis Teks Media : Suatu Pengatar untuk Analisis Wacana, Analisis Semiotik, dan Analisis Framing. Bandung: Remaja Rosdakarya.

Surat Kabar Harian 'Suara Merdeka', 18 Agustus 2008

Sunarto, 2009, Televisi, Kekerasan, dan Perempuan. Jakarta: Kompas.

Tolson, Andrew, 1993, Mediations: Text and Discourse ini Media Studies. London: Arnold.

Yatim, Debra. Media Dan Perempuan: Siapa Bercermin Pada Siapa?. Jurnal Perempuan edisi ke-6

Yayasan Jurnal Perempuan, 1998 Jakarta 